\title{
The Career
}

of Henry M. Farr,

Civil War Surgeon

Philip D. Jordan

The following article is based on a Civil War diary written by Dr. Henry M. Farr. An army physician's battlefield was different from that of a foot soldier or calvalryman, and Dr. Farr's observations help illuminate its characteristic adventure and travail. $-E d$.

The men of the Twenty-Fifth Iowa, Weary after Battles at Lookout Mountain and Taylor's Ridge, trudged into winter quarters at Woodville on December 23, 1863. Woodville, situated in the northeast corner of Alabama, was little more than a way stop on the Memphis and Charleston Railroad. ${ }^{1}$ It proved to be a dreary place to spend the holidays and was quite unlike Mt. Pleasant, Iowa, where the regiment was formed in September 1862 under the command of Colonel George A. Stone. ${ }^{2}$ In Alabama, no snow covered the ground and frosted trees. There were no frozen ponds like those at home on which to skate. No stockings hung in tents; and Christmas trees bright with candles and strings of popcorn and cranberries existed only in memories. To the boys of the North

'Farr's Civil War diary, beginning January 1, 1864 and concluding on January 5, 1865, mentions, under date of January 2,1864 , that the regiment was encamped at Woodville, Alabama during the winter of 1863-1864.

${ }^{2}$ For the information of the regiment, see Lurton D. Ingersoll, Iowa and the Rebellion (Philadelphia: J. B. Lippincott \& Co., 1866), 515-16; for a biographical sketch of Colonel George A. Stone, see A. A. Stuart, Iowa Colonels and Regiments: Being A History of Iowa Regiments (Des Moines: 1865), 407-14; for an obituary, see Annals of Iowa, 3d ser., vol. 5 (1901-1903), 158. 
the land was disappointing-flat with a little roll. Even hills and mountains seemed unattractive in a state which boasted of the beauty of its magnolias and jasmine.

Dr. Henry M. Farr, surgeon of the regiment, thought the weather ranged from disagreeable to pleasant, but noted in his diary that troops slogged through much mud. Farr, born in Huntington, Vermont on September 2, 1828, enrolled at Allegheny College in Meadville, Pennsylvania, at age twentyone. There he became an active member of the Philo-Franklin Literary Society and, at the close of his senior year, was named to give the valedictorian address at the commencement exercises in June $1852 .{ }^{3}$ His college years and his New England background prompted an intense interest in the anti-slavery movement and in the rapidly developing West. It was during this time that young Farr decided he would become a physician. He even dreamed that he might be successful as an army doctor on the expanding frontier.

Yet it is doubtful if Farr, when he began his medical education at Castleton Medical College in Castleton, Vermont, ${ }^{4}$ after graduation from Allegheny College, anticipated that at age thirty-six he would be stationed in Alabama with two "darky" servants to wait upon him. He probably would have been astonished, had he been able to read the future, to know that on January 2, 1864 he would be beating his colonel at chess and, during leisure hours, reading Dickens' Old Curiosity Shop. For the moment, before he moved to the young state of Iowa and before gathering clouds blew up a storm of rebellion, Farr was content to continue his medical studies.

From Castleton College, Farr went to Ann Arbor to devote the year 1853-1854 to further study at the University of Michigan Medical School. Then, for some now unknown reasons, he returned to Castleton, graduating in June, 1855. He probably hung out his shingle in that community, although he may

\footnotetext{
${ }^{3}$ The author is indebted to Robert L. McDonald, former student, who researched Farr's family background. Portrait and Biographical Album of Henry County (Chicago: Acme Publishing Company, 1888), 401, 356; Journal of Iowa State Medical Society, (May 1921), 11: 185; McDonald telephone interview, October 30, 1969, with Frank Farr, grandnephew of Henry M. Farr; Dorothy J. Smith, librarian, Allegheny College, to McDonald, October 9, 1969.

"The first medical school in Vermont, Castleton Medical College opened in 1818 and closed in 1854. It then became a state normal school, but continued to offer "scientific" courses. See Register of Physicians and Midwives [Henry County], Iowa, (n.p., n.d.), 1-2.
} 
have had a small rural practice near his parents' home in Huntington. He once wrote that he loved the Green Mountains, but apparently that affection was insufficient to keep him in Vermont for long. ${ }^{5}$

Sometime in late 1856, Farr started westward, carrying with him a carpetbag in which were stuffed a change of clothing, a set of pocket instruments, and two precious notebooks in which were written "tried and true" prescriptions. At least his professors had guaranteed their effectiveness. The doctor was headed for the Hawk-Eye State where a relative, Leonard Farr, had farmed in Salem Township, Henry County since $1841 .^{6}$ There he met, courted, and married his second cousin Hannah C. Farr, a lady of refinement and intelligence who had graduated from the Oxford Female Seminary, Oxford, Ohio. The two were married in Iowa City on October 12, 1856, but years later when Farr applied for a pension he could not recall the name of the clergyman. ${ }^{7} \mathrm{~A}$ month after the wedding Farr purchased about two and a half acres of land which touched the platted town of Salem on one corner. Hannah apparently taught school while her husband combined doctoring with farming. Two sons were born, but each died in infancy.

Salem was more than a typical farming village. Settled by Quakers about 1835, the community-at least a large portion of it-was violently anti-slavery. Its inhabitants felt no obligation to obey the Fugitive Slave Act of 1850 . Indeed, the town became an active station on the Underground Railroad. Farr felt at ease among Salem's residents and thoroughly approved of their vigorous efforts to help blacks to a life free from bondage. As times grew tense and the issues of states' rights and slavery stirred both patients and friends, Farr decided he

${ }^{5}$ Robert A. Green, associate dean for student affairs, University of Michigan Medical School, to McDonald, November 10, 1969; the Green Mountain statement was written on an undated scrap of paper between the leaves of a sort of scrapbook filled with miscellaneous clippings.

${ }^{6}$ For Leonard Farr, see Portrait and Biographical Album, 299.

'Mount Pleasant Free Press, January 25, 1894; the newly married couple possibly lived for a time in the residence of Leonard Farr. See Census Record of the Family of Leonard Farr, 1856, Salem Township, Henry County, Iowa, vol. 47, p. 781, line 133 in Iowa State Historical Department, Div. of Historical Museum and Archives, Des Moines; photostat, United States Pension Office, pension questionnaire, filled out, signed, and dated by Farr, March 19, 1915. 
would stand with Lincoln and the preservation of the Union. After all, he recalled that his maternal grandfather had served in the continental army, had been captured and sent to England to serve time in a military prison. ${ }^{8}$ There is some evidence, although it cannot be verified, that the doctor's buggy sometimes transported escaped slaves.

But neither anti-slavery sentiments nor patriotism prompted Farr to sell his farm and enlist as assistant surgeon in the Twenty-Fifth. These feelings play a role in his decision. There is no doubt of that. In the first place, Farr was a better doctor than a farmer. He recognized that his practice would fall off and his income decrease as more and more left for military service. Farr and Colonel Stone were friends, and there is little doubt but that Stone was more than willing to secure a commission for the doctor. There was another factor: the pay of an assistant surgeon was fixed and sure. Farr no longer would have to accept some payment for his services in kind-a bushel of potatoes for treating a case of measles, a chicken for lancing a boil, two pounds of butter and one of sausage for setting a simple fracture. ${ }^{9}$

Farr was enrolled in the Twenty-Fifth on April 16, 1862. His immediate superior, the regiment's surgeon, was Dr. William S. Marsh, a long-time friend and a resident of Mt. Pleasant. The regiment went into preliminary training at Camp McKean, locally referred to as Camp Harlan, near Mt. Pleasant. Somehow or other, Farr secured a more than twenty-year-old copy of Hints on the Medical Examination of Recruits for the Army, and he, until he received current manuals, used the old pamphlet when he gave

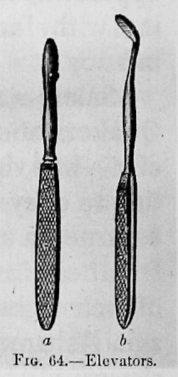

Elevators physical examinations to recruits. He paid particular attention to a paragraph which read:

They (Surgeons and Assistant Surgeons) will be particularly attentive in the examination of recruits, and will cause each recruit to be stripped of all his clothes, and to move about and ex-

'Pension questionnaire, March 19, 1915.

'Scrawled note on inside back cover of one of Farr's prescription books. 
ercise his limbs in their presence, in order to ascertain whether he has the free use of them; that his chest is ample; that his hearing, vision and speech are perfect; that he has not tumours, ulcerated or extensively cicatrized legs; rupture, chronic cutaneous affection, or other disorder or infirmity, mental or physical, which may render him unfit for the active duties of a soldier, or be the means of introducing disease into the army; and they will ascertain, as far as practicable, whether the recruit is an habitual drunkard, or subject to convulsions of any kind, or has received any contusions or wounds of the head which may produce occasional insanity. ${ }^{10}$

Farr remained with the regiment from April until the middle of July 1862. Then he was detatched and ordered to the United States General Hospital at Keokuk, Iowa, which was not a single structure, but was comprised of several buildings housing the sick and wounded. He served in the fourth ward of the Third Street Military Hospital. He first found room and board in a public house and then moved into a private residence. Wards, Farr found, were crowded. He saw food served which hardly benefitted those who needed special diets, although meals were classified as full diets, half diets, and low diets. A full diet noon meal, for example, consisted of pork and beans and bread pudding; a half-diet dinner consisted of mutton soup and meat, boiled potatoes, and bread; and the low-diet dinner consisted of farina gruel and bread. ${ }^{11}$

Butter, eggs, chickens, molasses, flour, cornmeal, crackers, lard, pepper, dried apples, and peaches, the Keokuk Daily Gate City noted on July 25, 1862, sometimes were served at least three times a week, but such items, in addition to ice, coal oil, and gas were not furnished by the government but were purchased from a special hospital fund. Farr's patients frequently received gifts of wines and jellies from

${ }^{10}$ Thomas Henderson, Hints on the Medical Examination of Recruits for the Army; and on the Discharge of Soldiers from the Service on Surgeon's Certificate. (Philadelphia: Haswell, Barrington, and Haswell, 1840), 8; these directions, generally speaking, varied little from those set down for surgeons in Revised United States Army Regulations of 1861 (Washington: Government Printing Office, 1863), 312-13.

"The material describing Farr's experiences in Keokuk is extracted from a journal he kept beginning on July 20,1862 and terminating some three or four weeks later. Contents are both unorganized and generally undated. For an account of the hospitals, see Gerald Kennedy, "U.S. Army Hospital: Keokuk, 1862-1865," Annals of Iowa, 3d. ser., vol. 40 (Summer 1969), 118-136; George W. Adams, Doctors in Blue: The Medical History of the Union Army in the Civil War (New York: Henry Schuman, 1952), 165. 
friends and relatives or from soldiers' aid societies sponsored by churches.

The fourth ward kept Farr busy from early morning until late in the evening, for he was responsible, according to his hospital notebook, for eightynine patients. They were infantrymen and cavalrymen not only from Iowa regiments but also from Illinois, $W$ isconsin, Michigan, and Missouri. Some from Missouri

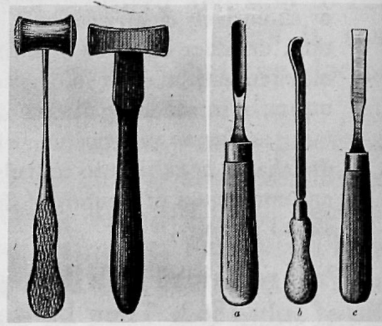

Hammers and Chisels may have been rebel prisoners. The majority of patients in ward four seem to have been sick, not wounded. Farr's notebook was filled with prescriptions used in the treatment of the sick. He set down directions for making a poultice, indicated the ingredients for several expectorants, listed recipes for tonics, and, among others, wrote numerous formulas useful in controlling dysentery and diarrhea. He seems to have favored a cordial made from six drops of oil of peppermint and twelve ounces of "perfectly pure and flavorless Alcohol."

Farr considered arrowroot pudding a "good diet for convalescents." Rub a tablespoonful of arrowroot, he said, with a little cold water. Add to it stirring constantly a pint of boiling milk; with this mix one egg and three teaspoonfuls of white sugar previously beaten together. Boil or bake, Among his other favorites were beef tea and mulled wine.

If Farr performed any surgery, he did not record it. Indeed, he entered only a few clinical reports of cases in the notebook kept while he was in Keokuk. One of these dealt with a male of about forty years who complained of chills and fever and coughed up blood. His skin was warm, and his head even warmer. Within twenty-four hours he became a "raving maniac." Farr ordered ice water placed on the sick man's head and blistered him. He prescribed quinine and ipecac. The patient failed to respond satisfactorily to this and other treatment, including morphine. He began to sink from exhaustion and died quietly five days after Farr first saw him. Farr listed 
the cause of death as "acute mania," cause unknown.

By August 29, 1862, when Farr terminated his duty in Keokuk, he had treated cases of acute and chronic diarrhea, typhoid fever, typhus, acute and chronic dysentery, scurvy, syphilis, gonorrhea, and, among others, delirium tremors, insanity, and paralysis. These diseases constituted the major ailments found both in Keokuk and throughout the Union army. Farr, in private practice, had treated all, but never in such large numbers. He believed, when he left Keokuk, that his

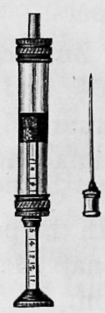

Syringe hospital experience, although arduous, better qualified him for service in the field. ${ }^{12}$

When he rejoined the regiment, Farr moved with it down the Mississippi River to Helena, Arkansas, where for a month it rested on its arms and then, after reconnoitering expeditions during November, once again moved by transport down river. On December 22, 1862, the Twenty-Fifth Volunteer Infantry was attached to General C. E. Hovey's Second Brigade of Steele's First Division, Fifteenth Army Corps. Farr, perhaps as a result of his close relationship with Colonel Stone, realized the stage was being set for an attack upon Vicksburg. He knew also that the First Division would be reinforced, in some manner or other, with forces commanded by General Sherman, who was moving down from Memphis.

Farr, although he participated in and witnessed actions at Chickasaw Bayou and Arkansas Post where the rebels punished the regiment, unfortunately jotted down no details. Neither did he record further actions of the Twenty-Fifth, although it and the Twenty-Sixth Iowa made, as Colonel Stone wrote, a determined but unsuccessful charge against Confederate works. Indeed, Farr failed to mention the fall of Vicksburg in May 1863. His only written note for that entire year was scribbled upon a scrap of paper and tucked in his diary for 1864. It read: "Jany 1, 1863. Pres frees slaves." Perhaps Farr did, indeed, keep an account of his duties and activities

${ }^{12}$ For a comprehensive list of diseases, see Revised Army Regulations, 337-42; Adams, Doctors in Blue, 222-30. 
during 1863 , but if he did it was not among his personal papers.

But beginning January 1 , 1864 and continuing until January 5, 1865, Farr kept an intimate and fascinating journal, one which illuminates both the personal and professional life of an army surgeon. $\mathrm{He}$, as mentioned earlier, was encamped with his regiment at Woodville, Alabama in January 1864. Farr wrote that all was relatively quiet, and that the men were well with the exception of a few cases of pneumonia. He had sufficient leisure to play chess, to read, and to mount his horse and "ride over to call on some Brother Surgeons" of the Second Bri-
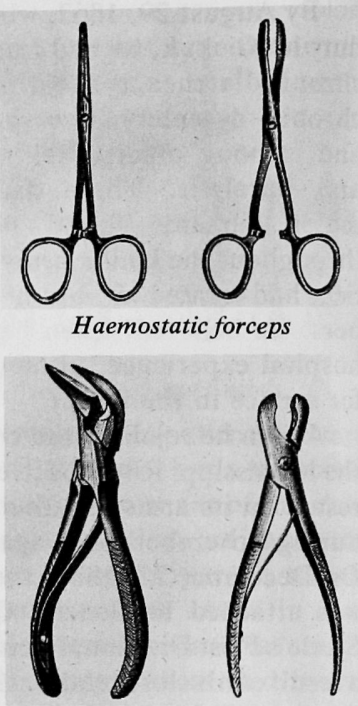

Bone forceps

gade. He wrote to headquarters requesting potatoes for the soldiers "as some were suffering for want of vegetable diet." $\mathrm{He}$ also asked for additional medical supplies. ${ }^{13}$

Uppermost in his mind, however, was a furlough, which he penned and sent on January 10. Nine days later it was granted and the next day Farr left Woodville for Iowa. He traveled by train from Nashville to Louisville, Kentucky, where he put up at the Gault House. Before going to bed he swallowed ten grains of quinine to keep off a threatened chill. The following morning Farr visited the paymaster and was given his salary for the period from December 1863 to January 1864 . With money in his pocket, he purchased a ticket to Iowa City via the New Albany and Chicago Railroad. For that he paid \$12.25.

${ }^{13}$ Unless otherwise indicated, the following material is taken from Farr's diary, beginning on January 1, 1864 and concluding on January 5, 1865. It is approximately six and a half inches tall and four inches wide. Bound in brown leather, it contains 163 pages, some written in ink and others in pencil. 
He next visited a Louisville shop to purchase a fine Waltham gold watch for himself and a smaller one for his wife. His slowmoving train which once "ran off the track" reached Lafayette, Indiana on January 23. From there he continued to Michigan City and on to Chicago, but he arrived in the Windy City too late to catch the train for Iowa City. He was, he wrote, "mad as a Dragon," and took a room at the Briggs House. There he met many officers going on leave and exchanged "good talk" with them. About an hour before midnight on January 24 , he crawled into a sleeping car on the Rock Island Railroad convinced he would arrive in Iowa City with no trouble.

Farr was mistaken. The next day, at about three in the morning, the tender broke two axles on four wheels, causing a delay of four hours. Finally, just in time for dinner, the train limped into Davenport. There he again took the cars for Iowa City, a three-hour ride. "Found wife," he wrote, "waiting for me at station. Mutual oscultory [sic] salutations!"

A twenty-day leave passes quickly. Dr. and Mrs. Farr visited relatives in Salem, Mt. Pleasant, and Columbus City. In Mt. Pleasant, he sat for a photographer and deposited some sixteen hundred dollars in the bank. Farr grumbled a bit at the price of his photographs-a dozen for \$7.50. Before he quite realized it, the furlough was over, and he was upon the " 4 o'clock train for Dixie." Farr's return to camp was uneventful, although he lost his valise in Chicago, was obliged to lay over in Indianapolis, Indiana, and, because of poor connections, wasted time in Louisville. He had purchased a Smith and Wesson revolver and a hundred cartridges. for fifteen dollars in Chicago. "When I get back," he wrote, "the Rebels better look out." The gun was heavy in his pocket during his sojourn in Nashville, for he set out on foot to visit the Tennessee State House and visited military hospitals.

When, on February 13, he finally arrived at Woodville, he was surprised to learn that the regiment had moved to Chattanooga. Hastily gathering his medical bag and his case of instruments, Farr caught a freight train to Chattanooga, where he reported for duty. He arrived just in time, for the Twenty- 
Fifth Iowa was already beginning to move into east Tennessee. ${ }^{14}$ After marching all day, the men went into camp on a farm owned by a Confederate. The weather was cold, and Farr almost froze. February 19 was so disagreeable that the troops did not move. Farr described the day in a few sentences: "Bought a new flannel over-shirt of Sutler for \$7.00! Got a door for a bed, wrote a letter, took a dose of quinine. Spread my blankets \& went to bed." The next day, he purchased two roasted chickens for $\$ 1.50$ and was vexed because they were only "about the size of Quails." A few days later, he paid fifty cents for eggs, and noted that a fellow surgeon "paid a Darkey $\$ 1.25$ for a Turkey."

On March 1 the regiment was ordered to Cleveland, Tennessee. Rain soaked the troops. Rumor had it that they soon would go into battle. Wagons mired in mud while horses pulled and strained. But the expedition was a failure, for the force failed to find the enemy. "The object of our trip," wrote Farr, "from Chattanooga to Cleveland Tenn I never found out; nor do I know why we were there ordered in line of battle as no enemy was near unless it was for practice." The journey did, however, give Farr his first opportunity to practice with his revolver purchased in Chicago, but he "couldn't hit the mark." He sold the gun a few days later.

By March 7, the Twenty-Fifth had returned to Woodville, where it remained until May 1, when it broke camp to participate in the famous "march to the sea." Farr, during that period, busied himself with requisitioning medical supplies, drawing rations, and filling out innumerable forms. ${ }^{15}$ Most of the sick suffered from pneumonia. He supervised the exhuming of a soldier's body, placed it in an air-tight coffin, and shipped it to Burlington. He treated a sentry who accidentally

${ }^{14}$ Fuller accounts of Farr's regiment in its march to the sea may be found in Stuart, Iowa Colonels, 307-14; S. H. M. Byers, Iowa in War Times (Des Moines: W. D. Condit \& Co., 1888), chaps. 25, 26, p. 530-32; Lurton D. Ingersoll, Iowa and the Rebellion (Philadelphia: J. B. Lippincott \& Co., 1866), chap. 29. An indispensable guide is E. B. Long (with Barbara Long), The Civil War by Day An Almanac, 1861-1865 (Garden City: Doubleday \& Company, Inc., 1971).

${ }^{\text {is }}$ The forms Farr filled out included requisitions for medical and hospital supplies; amount of medicine purchased by surgeons; return of medical and hospital property; quarterly abstracts of medical and hospital property received and issued; amount of clothing, arms, equipments of patients in hospitals; amount of furniture, cooking utensils, and bedding in use; prescription book, diet book, and diet table; and roll of soldiers employed in extra duty as cooks and nurses in hospitals. 
shot himself while on picket duty. He spent his evenings visiting fellow officers and writing letters.

Snow, which the Iowans so desperately wanted for Christmas, finally fell-eight wet inches of it-on March 20. Soldiers were "snowballing like a pack of schoolboys." A drenching rain followed the snow. Ice, an inch thick, made drill difficult. The number of men at sick call increased, and it was not long before those who pined for a white Iowa winter cursed the inclemency of the magnolia state.

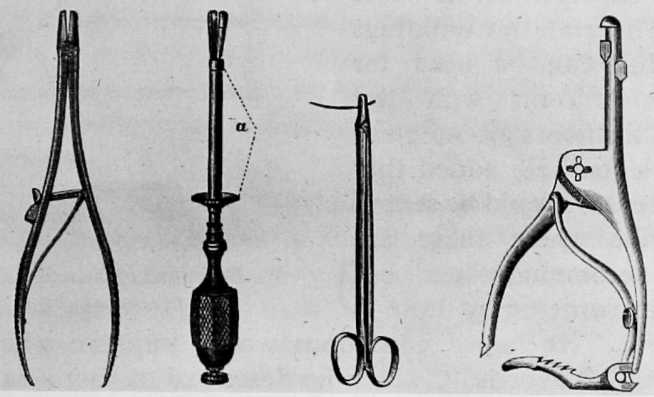

Needle holders

Mail call was about the only event which raised the men's spirits. They stood patiently in line for as long as an hour to receive letters from home. One snowy day Farr read a letter from his wife and was horrified to learn that she had lent without security a large amount of the sum he had deposited in Mt. Pleasant when he was on furlough. He immediately penned a note rebuking her and suggesting that she be more prudent with money as the salary of an assistant surgeon was only about fifty-three dollars a month and that of a surgeon in the neighborhood of eighty dollars. Early in April, when the weather was pleasant, another letter from Mrs. Farr carried the news that she was most unwell. She regretted making a loan without security.

It was then that Farr first doubted the wisdom of remaining in the army. Although he had enlisted as an assistant surgeon with the rank of captain and was promoted to surgeon on March 1, 1863 with the rank of major, he was growing weary 
of army routine, of army paper work, and of army life generally. He was satisfied with the actual practice of medicine in the field, but was critical of the conditions under which he worked. After deliberating, he decided to remain in the service a little longer.

Again and again, he voiced his discontent and wrote sharp criticisms of field hospitals. One example is sufficient. On April 21, he wrote that "There are no buildings here that can be used for Hospitals. Tents with wet ground for floors are no place for Patients." He added that serious cases should be sent to Huntsville where there are better accommodations, but it is not so ordered by those in
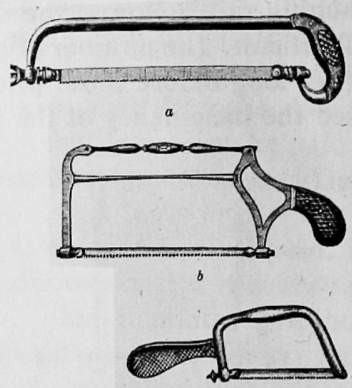

a, Bow saw; b, Butcher's saw; c, Metacarpal saw authority." He hoped conditions would improve when the regiment left Woodhill, which he described as just a railroad station with a few buildings and a water tower.

The regiment left Woodhill, Farr riding his horse "Fox," on May 1, 1864. On May 7, General Sherman began his famous march on Atlanta. In preparation for the campaign, the Twenty-Fifth Iowa was assigned to the Second Brigade, which was made up of troops from Iowa-the Fourth, Ninth, and Thirty-First regiments of Infantry. This Iowa Brigade of the Fifteenth Corps began fighting its way into Georgia and first faced enemy fire at Resaca, a town at the end of Buzzard's Root Gap and not too far from Snake Creek Gap. Farr recorded the action:

May 12. Some Rebels being seen by our men we were ordered in line of battle to meet any attack. At 11 o'clock at night orders came to move in the morning with 3 days rations and without knapsacks. We were now near the outlet of Snake Creek Valley and not far from the Rail Road.

May 13. Battle of Resaca Begins. I followed on foot with our regiment. dressed wounds on the field. whenever a man was 
hit Bullets \& shells filled the air \& I expected every minute to get hit but did not.

May 14. Battle raged all day but no casualties in 25th Ia. In the evening our 1st and 3d Brigades made an assault \& took an advanced position. Our regiment sent to support a battery. In the night our Regiment occupied a hill in advance. Something gained by our army but nothing decisive. We now have the whole Rebel army on our front but I see Sherman \& Hooker are here, and we feel safe.

May 16. The Enemy retreated last night, and our Regiment was the first to occupy their works this morning. our Col Stone was placed in command of the town [Resaca] but in a few hours we were ordered to Join our Corps in pursuit of the retreating enemy.

The battle of Resaca was the first major engagement which forced Confederate forces to abandon Snake Creek Gap and their advanced position along Rocky Face Ridge.

The Resaca action kept Farr busy treating the sick and wounded and supervising the burial of the dead. He was horrified to find the bodies of two Yankees who were stripped of clothing by rebels. De-

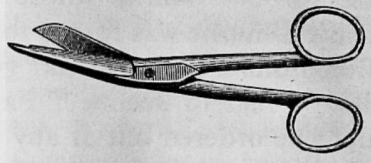

Dressing scissors spite the confusion and the most constant sound of artillery fire, he found time to enter in his journal the fact that General Sherman had issued a circular denying that he had forbidden the mailing of letters to the North and to state clearly the objective of the current campaign: "Our objective point is Atlanta \& so far we have good success."

As the regiment pushed toward Dallas and beyond, it met increased resistance which resulted in a five-day battle. Farr wrote a colorful account of an engagement on May 28:

Division Hospital and Train sent back to safer position. Solomon Clark wounded in head by ball. About 4 p. m. Rebels made a fierce attack on our left wing. 2 Brigade in reserve rushed at "double quick" to the front. Gen. Logan on his black Charger waving his sword \& rushing into the thickest of 
the fight was a picturesque figure. The artillery horses on the run; the soldiers in line with flags, at their utmost speed \& surgeons followed by ambulances, bringing up the rear, was a sight to be long remembered. Then came the terrible roar of battle, but it did not last long, for the enemy broke and fled.

On May 31, when things had quieted a bit, Farr wrote his wife "to let her know I am not killed yet-but no knowing but I will be soon, for bullets \& pieces of shells, fill the air." By June 3, the weary Twenty-Fifth was placed in reserve. Seven days later it marched to Kenesaw Mountain to engage in heavy fighting. General Johnson withdrew his forces on July 2, and the following day Sherman's army passed Kenesaw Mountain and, passing through Marietta, faced Johnson's new line along Nickajack Creek. The Twenty-Fifth was assigned to provost guard duty in Marietta, an attractive small town only twenty miles from Atlanta.

Farr found that all the "native" doctors had left Marietta, so that numerous residents came to him to be treated. He did care for one family whose children were down with the measles, but he was forced to refuse a prospective father who offered him a twenty-dollar gold piece if he would deliver his wife. "I had to decline," Farr explained, "as our regiment might be ordered out at any moment." It was well that Farr refused, for the regiment did march, camping for the night of July 4 on the beautiful campus of the Georgia Military Institute. The day following, the men of the Twenty-Fifth broke camp early in the morning, marched fifteen miles, with the enemy disputing each mile, and on July 6 pushed steadily on. That evening, said Farr, "From the top of a hill I saw Atlanta for the first time."

Although the fate of Atlanta was sealed between July 6 and the days following, the great battle to subdue the city took place on July 22 . Farr clearly recognized the importance of that day, for he recorded in capital letters the words "Great Battle of Atlanta." Then he wrote the following:

Early this morning it was found that the enemy had left their outer works, \& had retired within their inner line. Gen Hood had superceded Gen Johnson \& adopted new tactics. The main part of the Rebel army was hurled against the 17th 
Corps, on our left. One of our regiments \& a battery were taken prisoners. General McPherson was killed \& things looked squally; but General Logan takes command of the army of the Tennessee. Sherman sends up reserves the rebels are driven back with their inner works with great slaughter. Our Brigade was in reserve near Sherman's Quarters.

I saw Gen. McPherson's remains brought in. Soon I saw Gen. Logan coming towards Sherman at full speed \& seeing him approaching Sherman calls out to Logan, saying, "Logan! put a Brigade in the gap made by the captured regiment. The 17th corps are in reserve. You can have all the reinforcements there is room for. "Logan answers, "Gen. I have already done what you order. I had no time to wait for orders. "Sherman answers "all right-we'll give them h-ll before night."

Farr then began a new paragraph:

Dr. Grase' Battery was busy in our front across a field \& swamp. All at once we saw the Rebs leap over their breast works and charge the battery. They killed all the horses and many of the cannoniers. De Grase spiked his guns \& got away. Instantly our Brigade in reserve under Col. Stone was in line \& on the double quick over the field and through the swamp and charged the recently victorious Rebs. \& nearly (with the help of a battery behind on and eminence) annihilated them. Our loss in the battle of 22d July was heavy: but the rebels lost (it was claimed) over 10,000 men in killed and wounded and prisoners.

Despite such heavy fighting, Sherman was unable to enter the city until September 2 after General Hood had evacuated it the day before. Farr watched the Battle of Jonesboro through a telescope on September 1, but was obliged to lay the instrument aside in order to care for the wounded. He wrote that he worked nearly all night dressing wounds and performing surgery including an amputation of a rebel's thigh at the hip bone. September 2 was a day of double celebration for Farr. It was his thirty-sixth birthday as well as the day that "Atlanta was evacuated!!" and was lost to entering Union forces.

The Twenty-Fifth Iowa then shifted its position to East 
months as an acting staff surgeon. A few days later, he strongly recommended Dr. Marsh as his successor, sending Marsh's credentials to Governor Samuel J. Kirkwood of Iowa. The Governor agreed, and on November 9, Marsh became regimental surgeon and on the same day Farr's "contract as Staff Surgeon came back 'approved' by Surg. Gen.”

During October and November, Farr busied himself with routine chores and personal business. On October 4 , when the regiment was camped near Marietta, he devoted much time to filling out papers and official forms. Soon after, he accompanied the regiment to Kenesaw Mountain and from there to Rome and Kingston. Then the Twenty-Fifth went on to Resaca. At Taylor's Ridge, there was a short engagement. Another brief battle took place in October, when Farr noted, the enemy "skedaddled." Meanwhile, Farr sold his valise and a gold pen.

The truth is that, after his ploy to become a staff surgeon was successful, Farr seemed to lose interest in his work and to look forward to release from any army medical duties. Now and again, he mentioned in his diary that sick men were treated or sent to hospitals, but the entries became briefer and less detailed. He did comment, on November 12, that "Sherman seems to have determined to burn the bridges behind him." He also indicated that he had paid off all his debts, although he did not enumerate them. He purchased another horse-a large black mare. When, on November 24 the regiment occupied a small town, Farr wrote that the men "were distributed among the houses of citizens as quarters. I had the luxury of sleeping in a good feather bed."

Each day, during the cold of late November, the Twenty-Fifth was on the move in the vicinity of Summerville and Ogeechee River. Farr, on December 10, noted with some pride that the troops were within six miles of Savannah. Savannah, of course, fronted on the sea. It was defended in part by Fort McAllister. The capture of fort and city, Farr noted "gives us communication with the sea $\&$ our own fleetso we now have a new base, and our campaign is a complete success so far." The fall of Savannah also offered opportunity for Farr to enjoy a horse race and to secure oysters for his 
table. He strolled through the city, visited a cemetery, and chatted with citizens. Christmas Day both officers and soldiers "spent a Merry Christmas to the best of their abilities." 16

Letters from Salem informed him that the community's two physicians had left their Iowa practices and "that the people want me to return as the war must end soon. I think I better secure the practice there while there is such a good opening." The next day, December 30, Farr made written application to the Medical Director to "have my contract annulled, if I can be spared from the service."

After mailing the request, Farr gave practically no time to caring for troops. Instead, he enjoyed the sights and amusement of Savannah, which Sherman described as a handsome city with trees and parks shaded by willow-leaf live-oak, "evergreens of exquisite beauty." Farr watched a review of fire companies, which were "mostly colored," visited a Confederate hospital, and dropped into a schoolroom where he found the teaching to be fairly good. He was impressed by monuments erected to "Gen. Greene \& Baron De Kalb of Revolutionary Fame." He ate his fill of seafood.

No mention was made of any damage inflicted on the city by Union forces. Farr ignored the fact that the cemetery he visited was being used as a stable yard for cavalry horses. Indeed, one could read the entire journal without realizing that Sherman's forces laid waste to Atlanta, lived off the country, recklessly destroyed property, and burned and pillaged. Farr did not even bother, during his last days in Savannah, to write of the regiment he was leaving. He only noted, on January 4, 1865 , that his contract was annulled and that he drew pay in the amount of $\$ 529$. He immediately took passage on the Louisa for Hilton Head and on to Port Royal, South Carolina, where he arrived after dark. Finding the hotels crowded, Farr "took up with a wooden settee for a bed." That entry closed the diary. There is no further record of his journey home to Salem.

${ }^{16} \mathrm{Farr}$ did not know, when he wrote of the fall of Savannah, that the very day he made the entry-December 22-Sherman wrote Lincoln: "I beg to present to you as a Christmas-gift the city of Savannah, with one hundred and fifty heavy guns and plenty of ammunition, also about twenty-five thousand bales of cotton." William T. Sherman, Memoirs of General William T. Sherman, 2v. (New York: D. Appleton and Company, 1875), 2:231. 
Happy to be out of the service and to find his wife not as ill as he anticipated, Farr resumed his practice. He purchased a lot in Salem upon which to build a residence, and, in 1867, maintained an office on the northwest corner of the town square ${ }^{17}$ Farr practiced in Salem and the adjacent country some fifteen years, bringing untold numbers of babies into the world, tending the sick, and sitting by deathbeds. He was the typical country doctor. If he kept diaries or journals, they have long since disappeared. At least, they have not been found.

By 1880 , Farr felt that his practice would be larger and his future brighter if he moved to Mt. Pleasant, which was growing in population, was the home of a college, and was a community where he had friends. On February 3, 1880, he purchased a residence at 408 West Washington Street. ${ }^{18}$ On March 1, he and his wife moved into their new house. Farr disposed of his Salem property later in the month. Soon after he purchased and moved into the combined residence and office on West Washington Street, Farr inserted notices in the local Free Press and the Mount Pleasant Journal. On March 18, 1880, the Journal carried the following:

H. H. Farr, M.D. will promptly attend all professional calls. Office at residence, three blocks West of Southwest corner of square,-late residence of Mrs. E. M. White.

It is difficult to determine exactly how his office was furnished, but he probably had an examination table, a wooden cabinet in which he kept vials and drugs, and a scale upon which he weighed ingredients when he mixed prescriptions. He brought both his personal pocket kit of small instruments and his army issue amputation case home. The latter, among other instruments, contained knives, probes, and a saw. He used a folding tongue depressor with a bone handle. A wellworn small box housed his hypodermic syringe, two needles, and two glass tubes filled with tablets of cocaine hydrochlorate and morphine sulphate and atropine sulphate. His prize possession, apparently purchased soon after he moved to Mt. Pleasant, was a large safe manufactured by the Victor Safe \& Lock Company of Cincinnati, Ohio. He wrote prescriptions on

${ }^{17}$ Town Lot Deeds, Henry County, Book G., 586-87; Salem Excelsior, May 4, 1867.

${ }^{18}$ Town Lot Deeds, Book G, 334. 
blanks furnished by H. T. Bird \& Company situated in Mt. Pleasant's Brazelton Block. More and more, he took prescriptions from a pocket medical formulary purchased in 1891 . He wore the little book almost to pieces. ${ }^{19}$

Despite an active practice, Farr found time to participate in local politics. For some reason or other, he was violently opposed to a municipally-owned waterworks, the major issue in the city election of 1885 . Running on the Independent Citizen's Ticket, Farr was elected a councilman from the third ward by a vote of ninety-seven to fifty-two ${ }^{20} \mathrm{He}$ was re-elected in 1887 and again in 1889. In the latter election, he won office by only two votes-seventy-three to seventy-one. He did not again run for office until 1894 . He was successful, served a two-year term and, primarily because he advocated municipal ownership of the gas company, was again elected in 1896. When his tenure ended, Farr no longer engaged in politics. ${ }^{21}$

For one thing, he was sixty-eight years old. His wife, Hannah, had died, after a prolonged illness, on January 19, 1894, and he was discouraged and lonesome. After he buried his wife, Farr moved from the old home to reside for a time with the family of William Waugh on West Clay Street, but the pull of memories forced him to return to the house on West Washington Street. ${ }^{22} \mathrm{He}$ was a member of the Board of Examiners of Henry County. Although financially secure, he turned a neat profit of about seventy per cent when in 1903 he sold to the state of Iowa some 135 acres of land in Center Township, property he had purchased in 1894 and $1900 .{ }^{23}$

After he passed the age of seventy-five, Farr married Mary Kate Chambers, a woman thirty-seven years younger. ${ }^{24} \mathrm{He}$

${ }^{19}$ The amputation case, tongue depressor, syringe box, and safe are in the possession of the author. The pocket medical formulary was C. Sumner Witherstine, International Pocket Medical Formulary (Philadelphia and London, 1891). On its blank pages, Farr wrote in numerous prescriptions.

${ }^{20}$ Mt. Pleasant City Council Records, Books, E. F. and C., passim; Mount Pleasant Journal, March 5, 1885; Mount Pleasant Free Press, March 5, 1885.

${ }^{21}$ Mount Pleasant Free Press, March 3, 10, 1887; Mount Pleasant Journal, March 3, 10, 1887; Free Press, March 7, 1889, March 5, 1896.

${ }^{22}$ Mount Pleasant City Directory, 1893, p. 135; Census Record of the Family of Wm. Waugh, 1895, vol. 340, p. 22, line 9, Mount Pleasant, Henry County, Iowa State Historical Department, Div. of Historical Museum and Archives.

${ }^{23}$ Land Deeds, Book 72, p. 162; Book 98, p. 306; Book 96, p. 85-86.

${ }^{24}$ This marriage is not recorded in the Henry County Courthouse. Telephone interview with clerk of court, December 21, 1976. See Probate, Estate of Henry M. Farr, Ex. District Court, 
continued to practice, although on a reduced scale, until his death on March 3, 1921 at the ripe old age of ninety-two. By then his Civil War experiences were almost forgotten by most of the residents of Mt. Pleasant, so that he generally was thought of by younger generations as an old doctor of the horse-and-buggy school. "Dr. Farr,"' said the Mount Pleasant Daily News on March 4, "was one of the finest men which this community hosted." His obituary called him an honorable man whose integrity was never questioned and an individual whose character was absolutely above reproach. Such words would have gratified the old man, but perhaps he would have been even more pleased if a simple sentence drawn from his journal had been quoted. On October 31, 1865, Farr wrote, "I have done what I could for Lincoln and the Union."

Henry County. Probate Docket No. 5, p. 458, box 751. Farr's will, dated October 8, 1906, named his wife, Kate C. Farr, as benefactor. She was eighty years old when she died in 1945. Probate, Estate of Kate C. Farr, Carl Jordan, Ex., District Court, Henry County, Probate Docket No. 5, p. 458, box 751 . 


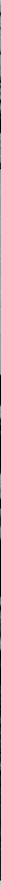

Mathew Brady photo of wounded soldiers outside a temporary infirmary.

The following poem, by Gary Gildner, is from his booklength sequence, Letters from Vicksburg (Unicorn Press, 1976). In the sequence John Blood, a semi-educated corporal in the Union Army, is writing to his wife back in Iowa. This poem concerns John Blood's visit to a hospital and the momentary "peaces" that the Union and Confederate armies agreed upon at certain times. The poem concludes with a reference to Confederate deserters. In his introduction to Letters from Vicksburg, Gildner says, in part, that he "tried to remain faithful to [Blood's semi-literate] grammar." The sequence of poems is based on ' 'Dear and Mutch Loved One' -An Iowan's Vicksburg Letters, " edited by Edward G. Longacre, Annals of Iowa, Summer, 1975. Letters from Vicksburg is now in its second printing and is available from Unicorn Press, P.O. Box 3307, Greensboro, N.C., 27402.-Ed. 
Copyright of Annals of Iowa is the property of State of Iowa, by \& through the State Historical Society of Iowa and its content may not be copied or emailed to multiple sites or posted to a listserv without the copyright holder's express written permission. However, users may print, download, or email articles for individual use. 